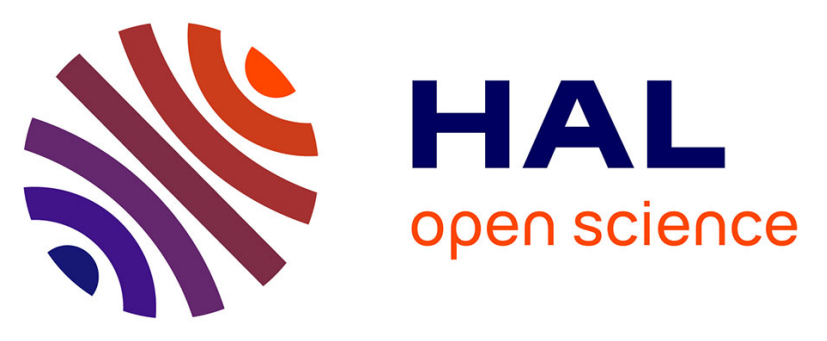

\title{
New insights into HcPTR2A and HcPTR2B, two high-affinity peptide transporters from the ectomycorrhizal model fungus Hebeloma cylindrosporum
}

Tobias Müller, Benjamin Neuhäuser, Uwe Ludewig, Gabriella Houdinet, Sabine Zimmermann, Pierre-Emmanuel Courty, Daniel Wipf

\section{To cite this version:}

Tobias Müller, Benjamin Neuhäuser, Uwe Ludewig, Gabriella Houdinet, Sabine Zimmermann, et al.. New insights into HcPTR2A and HcPTR2B, two high-affinity peptide transporters from the ectomycorrhizal model fungus Hebeloma cylindrosporum. Mycorrhiza, 2020, 10.1007/s00572-02000983-7 . hal-02922805

\section{HAL Id: hal-02922805 \\ https://hal.science/hal-02922805}

Submitted on 6 Jan 2021

HAL is a multi-disciplinary open access archive for the deposit and dissemination of scientific research documents, whether they are published or not. The documents may come from teaching and research institutions in France or abroad, or from public or private research centers.
L'archive ouverte pluridisciplinaire HAL, est destinée au dépôt et à la diffusion de documents scientifiques de niveau recherche, publiés ou non, émanant des établissements d'enseignement et de recherche français ou étrangers, des laboratoires publics ou privés.

\section{(1) (1) $\$$}

Distributed under a Creative Commons Attribution - NonCommercial - NoDerivatives 44.0 
1 New insights on HcPTR2A and HcPTR2B, two high affinity peptide transporters from the

2 ectomycorrhizal model fungus Hebeloma cylindrosporum

3

4 Tobias Müller ${ }^{1}$, Benjamin Neuhäuser ${ }^{2}$, Uwe Ludewig ${ }^{2}$, Gabriella Houdinet ${ }^{3}$, Sabine D.

5 Zimmermann $^{3}$, Pierre Emmanuel Courty ${ }^{4}$ and Daniel Wipf ${ }^{1,4}$

6

$7 \quad{ }^{1}$ University Bonn, IZMB, Transport in Ectomycorrhiza, 53115 Bonn, Germany

$8{ }^{2}$ Institute of Crop Science, Nutritional Crop Physiology, University of Hohenheim, Fruwirthstr. 20,

9 D-70593 Stuttgart, Germany.

$10{ }^{3}$ BPMP, Univ Montpellier, CNRS, INRAE, Montpellier SupAgro, Montpellier, France.

$11{ }^{4}$ Agroécologie, AgroSup Dijon, CNRS, Université de Bourgogne, INRAE, Université de Bourgogne 12 Franche-Comté, Dijon, France.

13

14 Number of figures: 6

15 Number of tables: 1

16 Supplementary material: 1 table and 3 figures

17

18 Corresponding Author: daniel.wipf@inrae.fr, Agroécologie, AgroSup Dijon, CNRS, Université de

19 Bourgogne, INRAE, Université de Bourgogne Franche-Comté, 17 rue Sully, 21000 Dijon, France,

20 Tel: + 333806934 52; Fax: + 0380693744.

21 ORCID B Neuhäuser: 0000-0002-2391-0598

22 ORCID U Ludewig: 0000-0001-5456-1055

23 ORCID S Zimmermann: 0000-0002-5020-1447

24 ORCID PE Courty : 0000-0003-2789-7818

25 ORCID D Wipf : 0000-0001-7197-5612 


\section{Abstract}

Unlike plants which mainly rely on the use of inorganic nitrogen sources like ammonium and nitrate, soil born microorganisms like the ectomycorrhizal fungus Hebeloma cylindrosporum can as well take up organic $\mathrm{N}$ sources like amino acids and peptides from the soil and exploit them as nitrogen and carbon sources. Two PTR-like peptide transporters have previously been identified and functionally expressed in the heterologous yeast. This study addresses the function and substrates of HcPTR2A and HcPTR2B transporters in detail by analysing the transport kinetics in Xenopus laevis oocytes. While both transporters mediated high affinity di- and tri-peptide transport, HcPTR2A also showed low affinity transport of several amino acids, mostly hydrophobic amino acids with large side chains.

Keywords: ectomycorrhiza, peptide transporter, gene expression, heterologous expression.

Declarations

Funding : Our work has partially been funded by grants from the Deutsche Forschungsgemeinschaft

(Gottfried-Wilhelm-Leibniz; DFG WI1994/2-1 and 2-2)

Conflicts of interest/Competing interests : not applicable

Ethics approval (include appropriate approvals or waivers): not applicable

Consent to participate (include appropriate statements): not applicable

Consent for publication (include appropriate statements): not applicable 
49 Nitrogen $(\mathrm{N})$ is one of the most limiting factors for plant growth even though it is among the most abundant elements on Earth (Vance 2001). The efficiency and ability to use such limiting nutrients is an important component of plant productivity (McKane et al. 2002). $\mathrm{N}$ forms available in the soil are largely dependent on different environmental factors like the climate, soil type, acidification and nitrification processes, but also on vegetation and management, such as fertilization. When the soil is relatively acidic, cold or poorly aerated, ammonium $\left(\mathrm{NH}_{4}^{+}\right)$will remain the predominant $\mathrm{N}$-form of plants, but under conditions favouring nitrification, the conversion to nitrate $\left(\mathrm{NO}_{3}{ }^{-}\right)$will follow ammonification (Marschner 2012). In forest soils, $\mathrm{N}$ is present either in its main inorganic forms $\mathrm{NH}_{4}{ }^{+}$and $\mathrm{NO}_{3}{ }^{-}$, or in organic compounds like amino acids, peptides and proteins (Marschner 2012; Chalot and Brun 1998).

Plants generally acquire $\mathrm{N}$ in its inorganic forms, followed by an intracellular reduction into $\mathrm{NH}_{4}{ }^{+}$, assimilation into glutamine and subsequently other amino acids and organic compounds. Since and peptides from the soil. the transport of peptides in fungi (Dunkel et al. 2013). Some PTRs are capable of transporting other nitrogen-containing substrates like nitrate (Chiang et al. 2004). In the ectomycorrhizal fungus (EMf) 
were previously isolated (Benjdia et al. 2006). The functionality of both transporters was shown by complementation of yeast mutants. Closer characterization by uptake studies with ${ }^{3}[\mathrm{H}]-$ labelled dipeptides could only be performed for HcPTR2A, while a more detailed functional analysis of HcPTR2B was still lacking. It is worthwhile to note that a dipeptide transporter was characterized in another mycorrhizal association type, namely in an arbuscular mycorrhizal fungus (Belmondo et al. 2014).

In this study, we investigated and compared the transport characteristics of HcPTR2A and HcPTR2B in detail by functional expression in Xenopus laevis oocytes and confirmed high affinity peptide transport for both transporters. We identified a low affinity amino acid transport activity of HcPTR2A as well as the voltage-dependent substrate affinities and transport kinetics for several peptides for both transporters. Moreover, differential expression patterns of these two transporters in the presence of the host plant argue for different specific roles in plant nutrition via the ectomycorrhizal association.

\section{7}

\section{Material and methods}

\subsection{Cloning of HcPTR2A and HcPTR2B into pOO2 and synthesis of cRNA}

For expression in $X$. laevis oocytes, the genes coding the HcPTR transporters were transferred from the yeast expression vector into the $X$. laevis expression vector pOO2 (Ludewig et al. 2002). Coding regions of the genes came from the cDNA library in Montpellier $(H c P T R 2 A$ and $H c P T R 2 B)$ and were inserted into the yeast expression vector pFL61 (Lambilliotte et al. 2004). For isolation of the genes, the vector was restricted with NotI and then ends blunted with T4-polymerase (Fermentas, Vilnius, Lithuania) following the manufacturer's instructions. pOO2 was blunted with SmaI and dephosphorylated to prevent re-ligation. Ligation was done as described by Sambrook et al. (1998) and the orientation was checked by PCR using a gene and vector specific primer pair.

For the synthesis of cRNA, $10 \mu \mathrm{g}$ of the cDNA containing pOO2 vectors were linearized by digestion with $M l u \mathrm{I}$ and linearization was verified by gel electrophoresis. The linearized and phenol chloroform 
100 cleaned plasmid was used as a template for cRNA synthesis using the "SP6 mMESSAGE 101 mMACHINE Kit" (Life Technologies GmbH, Darmstadt; Germany) following the manufacturer's 102 instructions. Quality of the cRNA was checked by RNA gel electrophoresis and cRNA concentrations 103 were determined photometrically.

\subsection{Preparation of Xenopus laevis oocytes and microinjection of cRNA}

106 Oocytes were surgically removed from anesthetized $X$. laevis. Oocytes were defolliculated by collagenase treatment $\left(\mathrm{Ca}^{2+}\right.$-free ND96 with 0,2\% collagenase; ND96: $96 \mathrm{mM} \mathrm{NaCl}, 2 \mathrm{mM} \mathrm{KCl}$, $1 \mathrm{mM} \mathrm{MgCl} 2,1.8 \mathrm{mM} \mathrm{CaCl}_{2}, 2.5 \mathrm{mM}$ sodium pyruvate, $5 \mathrm{mM}$ HEPES adjusted to $\mathrm{pH}$ of 7.4 by $\mathrm{NaOH}$ ). After five washing steps with $\mathrm{Ca}^{2+}$-free ND96 supplemented with $1 \mathrm{mg} \mathrm{ml}^{-1} \mathrm{BSA}$ solution, oocytes were manually separated for development stages V and VI (Dumont 1972). Before

111 microinjection of cRNA, the freshly prepared oocytes were stored overnight at $4{ }^{\circ} \mathrm{C}$.

112 Oocytes were microinjected with $50 \mathrm{nl}$ of $1 \mu \mathrm{g} \mu \mathrm{l}^{-1} \mathrm{cRNA}$ solutions with the help of a glass 113 micropipette and a micromanipulator (Drummond Scientific, Broomall, PA). Control oocytes were 114 injected with $50 \mathrm{nl} \mathrm{H} \mathrm{H}_{2} \mathrm{O}$. Before recordings, the injected oocytes were kept at $16{ }^{\circ} \mathrm{C}$ for three to five 115 days in ND96 solution. The buffer was changed every day depending on the oocytes and solution 116 conditions. Pipettes for injections and recordings were pulled using a Narishige PP-830 puller 117 (Tokyo, Japan) or L/M-3P-A puller (List Medical Electronic, Darmstadt, Germany), respectively.

\subsection{Measurements of steady-state inward currents across the oocyte plasma membrane}

120 Micropipettes pulled from $1.5 \mathrm{~mm}$ thin wall borosilicate glass GB150TF10 (Science Products GmbH, 121 Hofheim, Germany) were used for recordings. Pipettes were filled with $3 \mathrm{M} \mathrm{KCl}$ and connected to 122 the headstage using a chloride silver wire. Pipette resistance was 1.5 - 3.5 M $\Omega$ in ND96 solution. 123 Two-electrode voltage-clamp (TEVC) was done using a Dagan TEVC-200A amplifier (Dagan Corp, 124 Minneapolis, USA). Currents were recorded via a LM12 interface (Dagan Corp.) using Clampex 125 5.5.1 (Axon Instruments Inc., Union City, CA). 
126 For measuring the steady-state inward currents, the oocyte plasma membrane was held at $-30 \mathrm{mV}$, 127 and membrane currents were measured after stepping from the holding potential $\left(\mathrm{V}_{\mathrm{h}}\right)$ to test potentials $128\left(\mathrm{~V}_{\mathrm{m}}\right)$ between $-140 \mathrm{mV}$ and $+40 \mathrm{mV}$ in $20 \mathrm{mV}$ increments. Each voltage pulse was applied for $250 \mathrm{~ms}$.

129 The currents were filtered at $50 \mathrm{~Hz}$. Peptides and amino acid substrates were supplied by perfusion 130 of the bath in various concentrations indicated in the figures.

\subsection{RNA extraction and quantitative reverse transcription-PCR}

133 Growth conditions of $H$. cylindrosporum mycelium alone and in indirect contact with young seedling 134 roots of Pinus pinaster mimicking the symbiotic interface for $48 \mathrm{~h}$ were performed as described 135 (Becquer et al. 2017; Torres-Aqino et al. 2017). Briefly, fungal mycelia, grown for three weeks in 136 liquid cultures (N6), and pine seedlings, grown from seeds, cultivated separately in liquid nutritive 137 medium $\mathrm{N} 1$ for two months and finally washed $\left(\mathrm{CaSO}_{4} 0,2 \mathrm{mM}, \mathrm{pH} 5.5\right)$, were incubated together 138 for $48 \mathrm{~h}$ in an interaction medium $\left(\mathrm{MgSO}_{4} 0,2 \mathrm{mM}, \mathrm{CaCl}_{2}\right.$ 0,5 mM, MES $5 \mathrm{mM}$, TRIS $5 \mathrm{mM}$; $\mathrm{pH}$ 139 5.5). One fungal mycelium was incubated with three pine seedling roots (indirect contact) or in the 140 same conditions alone (three repetitions). RNA extraction from these fungal mycelia was performed 141 using the Spectrum ${ }^{\text {TM }}$ Plant Total RNA Kit (Sigma), RNA was treated by DNAse (Deoxyribonuclease 142 I, Amplification Grade, Invitrogen), and cDNA synthesis was performed by retrotranscription 143 (SuperScript ${ }^{\mathrm{TM}}$ III Reverse Transcriptase, Invitrogen).

144 RNA from P. pinaster-Laccaria bicolor ectomycorrhiza, harvested three and 28 days post-infection, 145 were gently provided by $\operatorname{Pr}$ F. Canavos (University of Malaga, Spain). Synthesis of these 146 ectomycorrhizas and RNA extraction are described in Flores-Monterroso et al. (2013). PCR reactions 147 and data analysis were performed as described in Courty et al. (2009) with 3 biological replicates. 148 Primers used for control (HcTub H. cylindrosporum $\alpha$-tubulin, GenBank accession number 149 CK993737 (Tatry et al. 2009) and LbEf-3 L. bicolor elongation factor (F: 150 CTCATCCTTCCTGCTCTTCTTCACG and R: CGGTGGCTTTTGTAAGTGAATCACG)) or for 151 analysis of HcPTR2 (HcPTR2A-F (TCGTTTCCCTCTCCACTGAC) and HcPTR2A-R 
(GCTCGTCCTCTTTGGCATC); HcPTR2B-F (GCGTTACTCAGCACGACCT) and HcPTR2B-R (ATCAGCGGCAATCACGAC)) and of LbPTR2 (LbPTR2A-F (GGCTTGCGGAGTGTTCTG) and LbPTR2A-R (TCTTCTTGAGGGCGGTGA); LbPTR2B-F (TCCTTGTCGCTGGTCTCG) and LbPTR2B-R (CGTTTTGGTGCCTTGGTG)) had an efficiency ranging between 90 and 110\%.

\subsection{Bioinformatic analysis}

Transmembrane domain analysis was performed using the TMHMM server (http://www.cbs.dtu.dk/services/TMHMM/). The peptide transporter sequences from H. cylindrosporum were obtained from the JGI project (https://genome.jgi.doe.gov/Hebcy2/Hebcy2.home.html). An additional set of 54 peptide transporter proteins from fungi and plants were obtained from the NCBI database or the JGI Mycocosm project (https://genome.jgi.doe.gov/mycocosm/home). Protein sequences were aligned using the ClustalW and their evolutionary relationship was inferred using the maximum-likelihood algorithm with bootstrap (1000 replicates). Evolutionary analyses were carried out in MEGA7 (Kumar et al. 2016). 3D protein structures of HcPTR2A and 2B have been predicted using Swiss Model (https://swissmodel.expasy.org/; Waterhouse et al. 2018).

\section{Results}

\subsection{PTR genes of Hebeloma cylindrosporum and predicted proteins}

Initially, HcPTR2A and HcPTR2B had been identified by a functional yeast complementation screening of a cDNA library as peptide transporters (Benjdia et al. 2006). Sequencing of the H. cylindrosporum genome among other EMf (Kohler et al. 2015) allowed detailed analyses of these PTR genes and gene products. The sequences of $H c P T R 2 A$ and $H c P T R 2 B$ are randomly distributed in the genome (scaffold 3 and 22, respectively) whereas in other EMf, e.g. Suillus luteus, duplicated genes are on the same scaffold (Table S1). The length of the genomic nucleotide sequences for $\operatorname{HcPTR} 2 A$ and $H c P T R 2 B$ are of 2,486 bp and 2,452 bp, respectively (Table S1). The coding exon 
sequences for these PTR genes were confirmed by EST alignment and cDNA sequencing; they are interrupted by short introns with a mean length of 55 and $58 \mathrm{bp}$, respectively. The actual number of introns is 13 for $H c P T R 2 A$ and 11 for $H c P T R 2 B$ (Table S1, Figure S1), which is similar to PTR transporters from other basidiomycetes, which normally show between 9 and 14 introns. The deduced protein sequences of $H c P T R 2 A$ and $H C P T R 2 B$ genes showed a length typical for fungal dipeptide transporters (591 aa and 603 aa, respectively) (Table S1). The THMM and Swissmodel predicted proteins with 10 and 11 transmembrane domains, for HcPTR2A and HcPTR2B, respectively (Figure $\mathrm{S} 2$ ). The sequence identity between the two proteins is $42.3 \%$. A phylogenetic classification of the two HcPTR transporters is given in Figure 1.

\subsection{Current/voltage (I/V) relationships at saturating substrate concentrations for HcPTR2A}

To study the biochemical properties of HcPTR2A and HcPTR2B, four peptides exhibiting different properties were chosen. Two of them, LeuLeu and LeuLeuLeu, had been already tested in Saccharomyces cerevisiae (Benjdia et al. 2006). Previous uptake experiments with radiolabelled ${ }^{3}[$ H]LeuLeu showed no significant uptake by HcPTR2B (Benjdia et al. 2006). Here, we expressed both transporters in $X$. laevis oocytes and measured inward currents induced by different peptides. At neutral $\mathrm{pH}$, only negligible small ionic currents were elicited by the peptides, but substantial ionic inward currents of up to $0.5 \mu \mathrm{A}$ were elicited at acidic external $\mathrm{pH} 4.5$. I/V relationships at saturating substrate concentrations were normalized to the maximum induced steady-state current for each oocyte and are given in Figure 2 for both transporters, HcPTR2A and HcPTR2B, for different peptides. Only inward currents were observed, in accordance with the fact that the (uncharged) substrates were applied externally and uptake was in form of peptide co-transport with $\mathrm{H}^{+}$, driven by the negative membrane potential. At positive potentials, the currents asymptotically approached zero, but no outward currents were observed. For comparison, water-injected oocytes were exposed to the same peptides, but no ionic currents were elicited, clearly showing that the recorded currents were carried by the respective heterologously expressed transporters. 


\subsection{Kinetics of HcPTR2A and HcPTR2B mediated peptide transport}

206 Next, we measured the concentration-dependent transport rates. According to the screening results in 207 yeast, several substrates were tested for their ability for transport competition (Benjdia et al. 2006). HcPTR2A as well as HcPTR2B were both capable of transporting the LeuLeu, as well as the

LeuLeuLeu peptide, over a broad range of concentrations (Figure 3). The $\mathrm{K}_{\mathrm{m}}$ of HcPTR2A and

210 HcPTR2B for the uncharged di- and tripeptides LeuLeu and LeuLeuLeu, and for the zwitterionic 211 peptide LysAsp were in a similar range, around 0.5-0.8 $\mu \mathrm{M}$ and 1.5-4 $\mu \mathrm{M}$, respectively (Table 1, 212 Figure 3).

213 For the neutral dipeptide GlyAsn, containing the small glycine and polar asparagine, HcPTR2A and 214 HcPTR2B had a much lower affinity with a $\mathrm{K}_{\mathrm{m}}$ in the range of $91 \mu \mathrm{M}$ and $33.7 \mu \mathrm{M}$, respectively. For 215 the dipeptides LysAsp and LeuLeu, and the tripeptide LeuLeuLeu, the transport saturation of both 216 transporters was already reached at substrate concentrations below $30 \mu \mathrm{M}$. In contrast, for GlyAsn, 217 significantly higher concentrations were needed to saturate the transport of HcPTR2A and HcPTR2B, 218 in a range above $300 \mu \mathrm{M}$ and $100 \mu \mathrm{M}$, respectively (Table 1, Figure 3).

219 In all cases, when the currents induced from $-40 \mathrm{mV}$ to $-140 \mathrm{mV}$ were sufficiently large, we quantified 220 the affinity for each membrane potential. For HcPTR2A, these calculations could be done for all 221 peptides, while for HcPTR2B, only the currents induced with LysAsp and LeuLeu were sufficiently 222 large for this analysis. Interestingly, the concentration of peptides, at which the transport was halfmaximal saturated $(\mathrm{Km})$ increased with more negative membrane potentials (Figure 4), suggesting that the $\mathrm{K}_{\mathrm{m}}$ was voltage-dependent. This was irrespective of the type of peptide tested and suggests that both transporters had higher affinity to their substrates at less negative voltages.

\subsection{HcPTR2A mediates low affinity transport of large hydrophobic amino acids}

228 Since all four tested peptides elicited large ionic currents in HcPTR2A, we further tested whether this 
230 acids Leu, Phe and Met elicited the strongest currents and induced substantial inward currents at 231 millimolar concentrations (Figure 5A). Transport rates were measured over a broad range of 232 concentrations and revealed that the transport saturated with low affinities $\left(\mathrm{K}_{\mathrm{m}}=3.37,4.75\right.$ and $233 \quad 3.52 \mathrm{mM}$ for Leu, Phe and Met, respectively) (Figure 5B). Non-injected control oocytes did not show 234 amino acid-induced currents, confirming that the amino acid transport was carried by HcPTR2A. 235 However, only few of the 20 proteinogenic amino acids were transported by HcPTR2A at a substrate 236 concentration of $1 \mathrm{mM}$. In addition to Leu, Phe and Met, the large neutral amino acid Tyr induced 237 substantial currents (Figure 5C). Smaller currents were elicited by the small hydrophobic amino acids 238 Val and Ile, as well as the polar Asn and the charged Arg and Glu (Figure 5C).

\subsection{HCPTR2B was down-regulated in the presence of a plant partner}

241 Expression of both peptide transporters was quantified on the transcriptional level in fungal mycelia 242 alone compared to mycelia incubated for $48 \mathrm{~h}$ in the presence of young pine seedling roots (Figure 243 6). The expression of $H c P T R 2 A$ was similar in free-living mycelium and in mycelium in indirect 244 contact with $P$. pinaster roots under same culture conditions. Interestingly, HcPTR $2 B$ was 245 significantly down-regulated in presence of its plant host in the conditions of the device mimicking 246 the interaction space already after $48 \mathrm{~h}$ arguing for a tight regulation at early stages of symbiotic 247 signalling between ectomycorrhizal fungus and roots of the host plant. In addition, expression of both 248 peptide transporters was quantified on the transcriptional level in P. pinaster-Laccaria bicolor 249 ectomycorrhizal roots, harvested three and 28 days post-infection. LbPTR2A was only expressed in 250 functional ectomycorrhizal roots (28 dpi). LbPTR2B was significantly down-regulated 8,5 times in 25128 dpi ectomycorrhizal roots compared to 3 dpi ectomycorrhizal roots (normalized expressed of $0.68 \pm 0.16$ versus $5.77 \pm 0.38$ ).

\section{Discussion}


Previously, two di- and tripeptide transporters (HcPTR2A and HcPTR2B) from H. cylindrosporum were isolated and partially characterized (Benjdia et al. 2006). For PTR2A, a $\mathrm{K}_{\mathrm{m}}$ value of $1.46 \mu \mathrm{M}$ for LeuLeu was estimated from radiolabelled dipeptide uptake experiments in the $S$. cerevisiae mutant LR2 expressing HcPTR2A. The transport of other substrates was inferred from competition experiments (Benjdia et al. 2006). However, uptake experiments for PTR2B with ${ }^{3}[\mathrm{H}]$-LeuLeu in

S. cerevisiae previously showed a very high standard deviation so that no $\mathrm{K}_{\mathrm{m}}$ value could be estimated 261 in yeast. To gain a better understanding regarding the transport properties and the substrate specificities of HcPTR2A and HcPTR2B, both genes were expressed in X. laevis oocytes. Both transporters elicited significant inward currents when oocytes were perfused with a peptidecontaining solution at acidic $\mathrm{pH}$, in line with their function as proton co-transporters. Similarly to RiPTR2, a peptide transporter of the arbuscular mycorrhizal fungus Rhizophagus irregularis (Belmondo et al. 2014), HcPTR2A showed a wide substrate spectrum with very high affinities for LysAsp, LeuLeu and LeuLeuLeu. GlyAsn was transported with a significant lower affinity compared to the other peptides. Similar as in the heterologous host yeast, HcPTR2A had a lower affinity for peptides starting with a Gly. These results correspond to what has been observed in the uptake experiments of HcPTR2A in S. cerevisiae (Benjdia et al. 2006) and confirm the very high affinity of HcPTR2A $\left(1.46 \mu \mathrm{M}\right.$ for ${ }^{3}[\mathrm{H}]$-LeuLeu in $S$. cerevisiae uptakes and $0.73 \mu \mathrm{M}$ for LeuLeu at $-140 \mathrm{mV}$ in oocytes). The slight difference can be due to the fact that in uptake experiments the membrane potential is not tightly controlled as in the voltage-clamp experiments and will be an average of all $S$. cerevisiae cells. Whereas the resting membrane potential of plants is between $-120 \mathrm{mV}$ and $-180 \mathrm{mV}$ (Marschner 2012) the fungal membrane potential is expected even more negative, it can be down to -300 mV (Slayman 1985). Interestingly, the $\mathrm{K}_{\mathrm{m}}$ value for HcPTR2A increased with more negative membrane potentials. A robust inward current was observed using GlyAsn as substrate. Further we observed solid inward currents when large, mainly hydrophobic, amino acids like Leu, Phe and Met were supplied in millimolar concentrations. The transport of these three amino acids was saturable as well but only reached half maximal transport rates at high concentrations of $\sim 3-5 \mathrm{mM}$. Therefore, 
281 it might be questioned whether this transport is physiologically relevant but affinity might also be 282 voltage-dependent as shown for other substrates.

283 The second peptide transporter HcPTR2B as well showed a high affinity for LysAsp, LeuLeu and 284 LeuLeuLeu. HcPTR2B showed a lower $\mathrm{K}_{\mathrm{m}}$ for GlyAsn $(33.7 \mu \mathrm{M})$ when compared to HcPTR2A. 285 However, transport affinities were not as high as observed for HcPTR2A in response to LeuLeu and 286 LeuLeuLeu. In contrast, the affinity to LysAsp and GlyAsn seemed to be higher.

287 These results indicate that both transporters are high affinity di- and tripeptide transporters, but have 288 differences in their substrate specificity. Both peptide transporters show high affinity levels that have 289 never been observed before for any plant or fungal peptide transporter from the PTR family. In $X$. 290 laevis experiments, a $\mathrm{K}_{\mathrm{m}}$ value of $33 \mu \mathrm{M}$ for LeuLeu could be estimated for a fungal peptide 291 transporter, originally identified from an Arabidopsis thaliana cDNA library (Steiner et al. 1994) but 292 then turned out to be a fungal contamination (Chiang et al. 2004). However, the $\mathrm{K}_{\mathrm{m}}$ value of fPTR2 293 does not increase with a more negative membrane potential as it could be shown for both 294 H. cylindrosporum peptide transporters. Yeast uptake experiments with this transporter resulted in a $295 \mathrm{~K}_{\mathrm{m}}$ value of $14 \mu \mathrm{M}$ for ${ }^{3}[\mathrm{H}]$-LeuLeu (Steiner et al. 1994) demonstrating the difference between both 296 heterologous expression systems explained by a series of possible differences in e.g. cytosolic and/or 297 membrane conditions. However, the results observed for H. cylindrosporum peptide transporters 298 expressed in yeast and X. laevis show similar characteristics.

299 Other characterised peptide transporters derived from plants like Vicia faba PTR1 (Km 20 mM; 300 Miranda et al. 2003), A. thaliana PTR1 (Km $56 \mu \mathrm{M}$ for AlaAla to $416 \mu \mathrm{M}$ for AlaAsp; Dietrich et al. 301 2004a) or A. thaliana PTR2 (Km $52 \mu \mathrm{M}$ for LeuLeu to 1,832 $\mu \mathrm{M}$ for AlaAsp; Chiang et al. 2004) 302 show lower substrate affinities. If also not all possible substrates were tested, the broad substrate 303 specificity of peptide transporters could be shown. This seems to be necessary as Dietrich et al. 304 (2004b) demonstrated that from the 400 dipeptides from degraded Rubisco only seven were present 305 more than six times in the intact protein, but most of them exist only one or two times (Dietrich et al. 306 2004a). 
307 Keeping the high substrate affinity of both $H$. cylindrosporum peptide transporters in mind the 308 question could be addressed if there is a reason for this. Therefore, one has to take a look at the 309 original habitat of $H$. cylindrosporum and $P$. pinaster. It is divided into two habitats, the "dune" 310 habitat where the percentage of organic matter ranges from $0.1 \%$ to $0.5 \%$ and the "forest" habitat 311 with up to $3 \%$ of organic matter (Guidot et al. 2002). This very low percentage of organic matter 312 could be an explainable reason for the high affinities of the peptide transporters.

313 It is worth to note that the transport rate of HcPTR2B is much lower than that observed for HcPTR2A. 314 Our results on HcPTR2A and 2B expression are in concordance with Plett et al. (2015) who studied 315 on arrays the expression level of Laccaria bicolor genes in the mycelium grown on medium 316 containing agar and in ectomycorrhizal roots of Populus trichocarpa-L. bicolor grown for 2, 4, 6 and 31712 weeks after contact. No expression was detected for protID668820 (homolog of HcPTR2A) 318 whatever the condition was. For protein ID301981 (homologous of HcPTR2B) the expression was 319 significantly reduced (from 6 to 30 times) in ectomycorrhizal roots whatever the time of contact 320 between the fungus and the roots. In addition, we also that expression of LbPTR2 was significantly 321 reduced in functional ectomycorrhizal roots of $P$. pinaster-L. bicolor. Here, we show even a strong 322 reduction of expression after only two days of indirect contact of the fungus with roots from young 323 pine seedlings arguing for an involvement in early signalling. Why should this peptide transporter be 324 so down-regulated? Might it be that both transporters are differentially localized, HcPTR2A perhaps 325 more in external hyphae exploring the soil, HcPTR2B more at the symbiotic interface, within the 326 Hartig net? In this case, it would be evident that plant factors are down-regulating expression of $327 H c P T R 2 B$ to avoid possible competition for peptides. One could suggest conserved roles for both 328 PTRs during evolution in ectomycorrhizal fungi. Previous analysis on the expression of both HcPTRs 329 in free living mycelium (Avolio et al. 2012) highlighted the fact that HcPTR2B was expressed under 330 all investigated conditions. So we could propose a role in a "basic" uptake of di- and tripeptides with 331 a high affinity in free living mycelium. Whereas $\operatorname{HcPTR} 2 A$, that has a higher affinity, would be 
332 involved in both free-living mycelium and mycorrhizal conditions. These results suggest that $H$. 333 cylindrosporum can perfectly adapt to conditions of a high competition for nutrient resources.

\section{Acknowledgements}

336 Our work has partially been funded by grants from the Deutsche Forschungsgemeinschaft (Gottfried337 Wilhelm-Leibniz; DFG WI1994/2-1 and 2-2).

\section{References}

341 Aerts R, Chapin FS (2000) The mineral nutrition of wild plants revisited: a re-evaluation of processes 342 and patterns. Adv Ecol Res 30:1-67.

343 Avolio M, Müller T, Mpangara A, Lange C, Becker B, Pauck A, Kirsch A, Fitz M, Wipf D (2012) 344 Regulation of genes involved in nitrogen uptake and metabolism by different $\mathrm{C} / \mathrm{N}$ ratios and nitrogen 345 sources in the model ectomycorrhizal fungus Hebeloma cylindrosporum. Mycorrhiza 22:515-524.

346 Becquer A, Torres-Aquino M, Le Guernevé C, Amenc LK, Trives-Segura C, Staunton S, 347 Quiquampoix H, Plassard C (2017) Establishing a symbiotic interface between cultured 348 ectomycorrhizal fungi and plants to follow fungal phosphate metabolism. Bio-protocol 7:e2577.

349 Belmondo S, Fiorilli V, Pérez-Tienda J, Ferrol N, Marmeisse R, Lanfranco L (2014) A dipeptide 350 transporter from the arbuscular mycorrhizal fungus Rhizophagus irregularis is upregulated in the 351 intraradical phase. Front Plant Sci 5:436.

352 Benjdia M, Rikirsch E, Müller T, Morel M, Corratgé C, Zimmermann S, Chalot M, Frommer WB, 353 Wipf D (2006) Peptide uptake in the ectomycorrhizal fungus Hebeloma cylindrosporum: 354 Characterization of two di- and tri-peptide transporters (HcPTR2A and B). New Phytol 170:401-410. 355 Chalot M, Brun A (1998) Physiology of organic nitrogen acquisition by ectomycorrhizal fungi and 356 ectomycorrhizas. FEMS Microbiol Lett 22:21-44. 
Chiang CS, Stacey G, Tsay YF (2004) Mechanisms and functional properties of two peptide 358 transporters, AtPTR2 and fPTR2. J Biol Chem 279:30150-30157.

359 Courty PE, Hoegger P, Kilaru S, Kohler A, Buée M, Garbaye J, Martin F, Kües U (2009) 360 Phylogenetic analysis, genomic organization and expression analysis of multicopper oxidases in the 361 ectomycorrhizal basidiomycete Laccaria bicolor. New Phytol 182:736-750.

362 Dietrich D, Hammes U, Thor K, Suter-Grotemeyer M, Fluckiger R, Slusarenko AJ, Ward JM, 363 Rentsch D (2004a) AtPTR1, a plasma membrane peptide transporter expressed during seed 364 germination and in vascular tissue of Arabidopsis. Plant J 40:488-499.

365 Dietrich FS, Voegeli S, Brachat S, Lerch A, Gates K, Steiner S, Mohr C, Pohlmann R, Luedi P, Choi 366 SD, Wing RA, Flavier A, Gaffney TD, Phillippsen P (2004b) The Ashbya gossypii genome as a tool 367 for mapping the ancient Saccharomyces cerevisiae genome. Science 304:304-307.

368 Dumont JN (1972) Oogenesis in Xenopus laevis (Daudin). 1. Stages of oocyte development in 369 laboratory maintained animals. J Morphol 136:153-179.

370 Dunkel N, Hertlein T, Franz R, Reuß O, Sasse C, Schäfer T, Ohlsen K, Morschhäuser J (2013) Roles 371 of different peptide transporters in nutrient acquisition in Candida albicans. J Eukaryotic 372 Cell 12:520-528.

373 Flores-Monterroso A, Canales J, de la Torre F, Avila C, Canovas FM (2013) Identification of genes 374 differentially expressed in ectomycorrhizal roots during the Pinus pinaster-Laccaria bicolor 375 interaction. Planta 237:1637-1650.

376 Guidot A, Gryta H, Gourbiere F, Debaud JC, Marmeisse R (2002) Forest habitat characteristics affect 377 balance between sexual reproduction and clonal propagation of the ectomycorrhizal mushroom 378 Hebeloma cylindrosporum. Oikos 99:25-36.

379 Kaye JP, Hart SC (1997) Competition for nitrogen between plants and soil microorganisms. Trends 380 Ecol Evol 12:139-143.

381 Kohler A, Kuo A, Nagy LG, Morin E, Barry KW, Buscot F, Canback B, Choi C, Cichocki N, Clum 382 A, Colpaert J, Copeland A, Costa MD, Dore J, Floudas D, Gay G, Girlanda M, Henrissat B, Herrmann 
S, Hess J, Hogberg N, Johansson T, Khouja HR, LaButti K, Lahrmann U, Levasseur A, Lindquist

384 EA, Lipzen A, Marmeisse R, Martino E, Murat C, Ngan CY, Nehls U, Plett JM, Pringle A, Ohm RA, 385 Perotto S, Peter M, Riley R, Rineau F, Ruytinx J, Salamov A, Shah F, Sun H, Tarkka M, Tritt A, 386 Veneault-Fourrey C, Zuccaro A, Consortium MGI, Tunlid A, Grigoriev IV, Hibbett DS, Martin F 387 (2015) Convergent losses of decay mechanisms and rapid turnover of symbiosis genes in mycorrhizal 388 mutualists. Nature Genet 47:410-415.

389 Kumar S, Stecher G, Tamura K (2016) MEGA7: molecular evolutionary genetics analysis version 3907.0 for bigger datasets. Mol Biol Evol 33:1870-1874.

391 Lambilliotte R, Cooke R, Samson D, Fizames C, Gaymard F, Plassard C, Tatry MV, Berger C, Laudie 392 M, Legeai F, Karsenty E, Delseny M, Zimmermann S, Sentenac H (2004) Large-scale identification 393 of genes in the fungus Hebeloma cylindrosporum paves the way to molecular analyses of 394 ectomycorrhizal symbiosis. New Phytol 164:505-513.

395 Ludewig U, von Wirén N, Frommer WB (2002) Uniport of $\mathrm{NH}_{4}{ }^{+}$by the root hair plasma membrane 396 ammonium transporter LeAMT1;1. J Biol Chem 277:13548-13555.

397 Marschner H (2012) Mineral nutrition of higher plants. Academic Press, San Diego.

398 McKane RB, Johnson LC, Shaver GR, Nadelhoffer KJ, Rastetter EB, Fry B, Giblin AE, Kielland K, 399 Kwiatkowski BL, Laundre JA, Murray G (2002) Resource-based niches provide a basis for plant 400 species diversity and dominance in arctic tundra. Nature 415:68-71.

401 Miranda M, Borisjuk L, Tewes A, Dietrich D, Rentsch D, Weber H, Wobus U (2003) Peptide and 402 amino acid transporters are differentially regulated during seed development and germination in faba 403 bean. Plant Physiol 132:1950-1960.

404 Plett J, Tisserant E, Brun A, Morin E, Grigoriev IV, Kuo A, Martin F, Kohler A (2015) The 405 mutualist Laccaria bicolor expresses a core gene regulon during the colonization of diverse host 406 plants and a variable regulon to counteract host-specific defenses. Mol Plant Microb Inter 28:261407273. 
Reddy VS, Shlykov MA, Castillo R, Sun EI, Saeir MH (2012) The major facilitator superfamily 409 (MFS) revisited. FEBS J 279:2022-2035.

410 Sambrook J, Fritsch EF, Maniatis T (1989) Molecular Cloning. A Laboratory Manual. Cold Spring 411 Harbor Laboratory Press, Cold Spring Harbor, USA.

412 Slayman CL (1985) Plasma-membrane proton pumps in plants and fungi. Bioscience 35:34-37.

413 Steiner HY, Song W, Zahng L, Naider F, Becker JM, Stacey G (1994) An Arabidopsis peptide 414 transporter is a member of a new class of membrane transport proteins. Plant Cell 6:1289-1299.

415 Steiner HY, Naider F, Becker JM (1995) The PTR family: a new group of peptide transporters. Mol 416 Microbiol 16:825-834.

417 Tatry MV, El Kassis E, Lambilliotte R, Corratgé C, van Aarle I, Amenc LK, Alary R, Zimmermann 418 S, Sentenac H, Plassard C (2009) Two differentially regulated phosphate transporters from the 419 symbiotic fungus Hebeloma cylindrosporum and phosphorus acquisition by ectomycorrhizal Pinus 420 pinaster. Plant J 57:1092-1102.

421 Torres-Aquino M, Becquer A, Le Guernevé C, Louche J, Amenc LK, Staunton S, Quiquampoix H, 422 Plassard C (2017) The host plant Pinus pinaster exerts specific effects on phosphate efflux and 423 polyphosphate metabolism of the ectomycorrhizal fungus Hebeloma cylindrosporum: a radiotracer, 424 cytological staining and ${ }^{31}$ P NMR spectroscopy study. Plant Cell Environ 40:190-202.

425 Vance CP (2001) Symbiotic nitrogen fixation and phosphorus acquisition. Plant nutrition in a world 426 of declining renewable resources. Plant Physiol 127:390-397.

427 Waterhouse A, Bertoni M, Bienert S, Studer G, Tauriello G, Gumienny R, Heer FT, de Beer TAP, 428 Rempfer C, Bordoli L, Lepore R, Schwede T (2018) SWISS-MODEL: homology modelling of 429 protein structures and complexes. Nucleic Acids Res 46:W296-W303.

430 Zak DR, Groffman PM, Pregitzer KS, Christensen SK, Tiedje JM (1990) The vernal dam: Plant431 microbe competition for nitrogen in Northern hardwood forests. Ecol 71:651-656. 